\title{
French Political Economy and Positivism (or how history of economic thought became mainstream economics)
}

Christophe Salvat ${ }^{1}$

Received: 21/07/2015 / Accepted: 02/03/2016

\begin{abstract}
This paper deals with French political economy under the Second Empire. It suggests that having been seriously weakened by internal dissents over the suitability of the historical method in economics, French political economy managed to reinvent itself during the last decade of Napoléon III's reign. Threatened by the emperor's personal suspicion towards free trade and the intellectual domination of positivism, economists experienced in the $1850 \mathrm{~s}$ one of the most difficult periods in their history. Yet, a decade later the tables seem to have turned. The institutional changes, brought forward by Victor Duruy, and the intellectual ascendance gained by economists such as Baudrillart, Wolowski or Dunoyer contributed to modernize and legitimize the outmoded and unimaginative political economy inherited from Say. They notably found in the history of economic thought a way to comply with the positive standards of the time but also to give back to political economy the respectability it had lost.
\end{abstract}

Keywords: positivism; political economy; Romanticism; Saint-Simonianism

JEL Classification: B10

[es] La Economía Política Francesa y el Positivismo (o cómo la historia del pensamiento económico se hizo ortodoxia económica)

Resumen. Este artículo estudia la Economía Política francesa bajo el Segundo Imperio. Sugiere que, habiendo quedado seriamente debilitada por las disensiones internas sobre la conveniencia de utilizar el método histórico en economía, la Economía Política francesa logró reinventarse durante la última década del reinado de Napoleón III. Amenazados por el recelo personal del emperador hacia el libre comercio y el dominio del positivismo, los economistas experimentaron en la década de 1850 uno de los períodos más difíciles de su historia. Sin embargo, una década más tarde parece que se dio un vuelco a la situación. Los cambios institucionales, producidos gracias a Victor Duruy, y el ascenso intelectual de economistas como Baudrillart, Wolowski o Dunoyer contribuyeron a modernizar y legitimar la obsoleta y poco imaginativa economía política heredada de Say. En particular, encontraron en la historia del pensamiento económico una forma de cumplir con los estándares positivos de la época pero también de devolver a la economía política la respetabilidad que había perdido.

Palabras clave: positivismo; economía política; Romanticismo; Sansimonismo

Clasificación JEL: B10

\section{Introduction}

Studies on nineteenth-century French economists traditionally fall into two groups: a first one centered on Jean-Baptiste Say and the Saint-Simonians, and a second one essentially devoted to the late nineteenth-century with Léon Walras and the French socialists. The period falling in between, say from 1840 to 1870 , is certainly a rich one for those interested in political thought, but it is usually considered as rather sterile for the historian of economic thought (with the notable exception of Cournot). After the death of Say in 1832, French economists are at a loss. The pop- 
ular disrepute they fell into and the political obstacles they had to face did not encourage them to produce original work. Much of their energy is spent in defending their liberal ideology against protectionism and socialism rather than engaging in theoretical debates. French political economy under the Second Empire has consequently been primarily considered as a period of transition, whose value is primarily drawn from its relationship to the preceding or successive periods.

It is my contention, however, that historians underestimated the institutional and theoretical changes experienced in economics during this period. I shall argue that the Second Empire (18511870) has played a decisive role both in the institutional development and the theoretical evolution of French political economy. It is indeed thanks to Napoleon III, or more specifically to his secretary of State, Victor Duruy, that political economy was (re)introduced in French universities, even if economists had to wait until 1877 to see their efforts duly completed. But even more importantly, I believe, French political economy was profoundly changed by the positivist philosophy that developed under the Second Empire. Devoted respectively to Saint-Simonianism and positivism, Napoléon III and Victor Duruy promoted, through the reorganization of the French education system, a 'positivist' political economy, which found its scientific legitimacy in history rather than in deductive logic. A major, but yet underrated, consequence of this was the growing ascendance of the history of economic thought and its development within the economic corpus.

In order to demonstrate my point, I propose to divide this article into three sections. The first section presents positivism and its contentious relationship with political economy. The second section describes the economists' response to this new wave of criticisms that add up with the attacks launched already by the sympathizers of Romanticism and Saint-Simonianism. It shows, in particular, how the Société d'économie politique and the Journal des économistes tried to addressed the issue of their lack of credibility. The third and last section explains how the nomination of Victor Duruy as the new secretary of State for Education completely shifted the balance of powers now benefiting the economists favorable to the historical method. This, in turn, contributed to the development of the history of economic thought.

\section{French Political economy and the rise of Positivism}

Positivism was first developed by Auguste Comte in the 1830s. But, as shown by the correspondence between Comte and John Stuart Mill, it was not until the publication of the last volume of Comte's Cours in 1842 that the pieces of his philosophy could finally be put together. Once complete, the philosophy could be explained, discussed and translated. In France, Emile Littré, the author of the eponymous dictionary, was one of his most devoted disciples. He published numerous books on Comte's positivism, including an Analyse raisonnée du cours de philosophie positiviste d'Auguste Comte (1845) and Auguste Comte et la philosophie positive (1863). In England, his work was abridged and freely translated by Harriet Martineau. From 1847, Comte redeveloped his positivism as a religious system (Bourdeau 2012), publishing notably a Système de politique positive, ou traité de sociologie instituant la religion de l'Humanité (1851-1854) and a Catéchisme positiviste (1852). The System of Positive Polity and the Catechism of Positive Religion were disavowed by a number of his followers, including Taine, Littré and Mill, and paved the way for new versions of positivism (Simon 1963). To some extent, positivism succeeded in being a popular philosophical system once Comte had been personally discredited.

Positivism, generally speaking, can be first construed as a reaction against Romanticism². Heir to the philosophy of the Enlightenment, on one side, and to Saint-Simonianism, on the other, Comte - who worked as Saint-Simon's personal secretary - opposed the Romantics' anti-carte-

\footnotetext{
Positivism was not a theory per se but rather a perspective that has been adopted in arts, science and literature in unison in the same manner that Romanticism had been twenty years earlier. In many ways positivism can be described as a reaction to Romanticism. While Romanticism commanded descriptions of inner feelings in literature or subjective expression of nature in art, positivism urged the artist to be as objective as possible in his portrayals of people and landscapes. The novels of Honoré de Balzac and Emile Zola perfectly illustrated this new 'scientific' trend. Despite being imaginary, each character was meticulously researched as was his social (and for Zola, his genetic) environment. All kind of intellectual activities were concerned by this sudden change of perspective, even the religious. With his Vie de Jésus, published in 1863, Jules Renan wrote the biography of Jesus as he would have written one of any other historical man. Social matters were also the object of a particular attention. When he described the Americans and their institutions in 1835 (and then in 1840 for the second volume), Alexis de Tocqueville gave a systematic and objective analysis of a whole society and, by doing so, opened the way to modern sociology.
} 
sian perspective and their presumed conservative ideology. Romantic authors, it is true, invariably treated tradition with the greatest respect, which often led them to take position against the French Revolution and for the Roman Catholic Church. For this reason, Comte used to refer to Bonald, Chateaubriand and Maistre as the "retrograde school". But Romanticism, it should be noted, also included "social" thinkers such as George Sand, Victor Hugo or Félicité de Lamennais (Picard 1944, Poisson 1931, Evans 1969). What really makes positivism and Romanticism incompatible is their respective views on reason and progress. Romanticism generally rejected the idea of historical progress (by rehabilitating the Middle-Ages for instance) and to highlight the difference of cultural values. Positivists, on the contrary, believed that history was a continuous progression towards perfection. For Comte, in particular, after lingering in the irrationality and obscurantism of the theological and then of the metaphysical stage, man had finally entered the positive or scientific stage in which he would eventually be able to reach perfection. This last stage would be characterized, in particular, by the development of an all-encompassing science of man in society.

French economists had seemingly nothing to fear from the rise of positivism. On the contrary, they had a common enemy in the Romantics, and the development of political economy, they could claim, was perfectly illustrating Comte's theory. Yet, positivists turned out to be the fiercest opponents of classical political economy. Their intellectual and institutional power, I shall argue, has been determinant in the restructuring of French political economy.

The conflict between positivism and political economy started with Comte's decision to exclude political economy from his classification of sciences. Comte had then ideological and logical reasons to disqualify political economy from the positive social sciences. He first strongly resented the liberal creed of the French economists. Once a disciple of Saint-Simon, Comte had developed close affinities with socialist writers and even considered the working class as his best ally (Pickering 2009, 268). Note that Comte's position towards economics radically changed around 1820 . When young, he regarded political economy (and particularly Jean-Baptiste Say's works) with deep admiration. His appreciation then evolved when he distanced himself from liberalism (Pickering 1993, Alengry 1899, Mauduit 1929). The main dissenting point was not, how- ever, a matter of principles, but a matter of method. Economists, for Comte, could not achieve positivity until they realized that social sciences are built upon observation and not speculation. He compared political economy to the political science imagined by Rousseau: a void intellectual construction based on universal principles that unavoidably lead to anarchy and social decaying. Far from meeting the positivist expectations of modern societies, the self-proclaimed science of economics was actually dragging metaphysics back into the nineteenth-century.

Comte's attitude towards political economy is representative of the global rejection that was the subject at the time. It is nevertheless a rather unfair critique as all French economists did not embrace the deductive method of the so called classical political economy. Mauduit suggested that his economic knowledge dated from his saint-Simonian period (Mauduit 1929, 70). This could partly explain it. I personally find it hard to believe, however, that he did not read (at least) Mill's Principles of Political Economy (1848), published just after they brutally stopped corresponding (Levy-Bruhl 2007). He certainly read and admired the works of his friend, Charles Dunoyer (Pickering 2009, 362-63). Dunoyer's economic theory stands apart in the first quarter of the 19th century. Like Comte, he believed that civilization is about to enter its fifth and definitive phase, the 'industrial state'. He also contributed with Sismondi to undermine Say's law by bringing out the cyclical nature of economic growth. Did he ever read Henri Baudrillart or Wolowski? Maybe not, but being close to Dunoyer, he must nevertheless have been aware of the internal debates that were taking place in the Société d'économie politique. The furor provoked by Wolowski's translation of Roscher's Principes d'économie politique in 1856 could hardly have gone unnoticed. In his preface, he entitled "On the application of the historical method to political economy", Roscher emphasized the role of history as means to uncover the truth ${ }^{3}$. He believed that economists, whose aim it is to show the universality of their economic principles, should naturally be open to the historical method. But, unlike most of the German economic historians, who belong to the Romantic rather than the positivist movement, Wolowski did not regard history as a counterargument to economic laws. From

Wolowski, L. (1856): “'De l'application de la méthode historique à l'étude de l'économie politique "' in G. Roscher, Principes d'économie politique Paris: Guillaumin. 
this point of view, his approach to political economy is closer to French positivism than German historicism. Even though it is hard to prove any direct influence from Comte and his disciples, it seems very likely that French political economy, like most other human sciences, has indeed been affected by positivism. Woloswki is but one example of the reluctant transformation undertaken by French political economy under the Second Empire. In keeping with their condescending response to Romanticism and Saint-Simonianism, which both previously stressed the importance of history in economic studies, French economists decided to ignore the positivist critic. They doggedly held to their positions in a last attempt to protect themselves from the epistemological and ideological consequences empiricism could cause to the orthodoxy led by Jean-Baptiste Say and his immediate successor, Pellegrino Rossi, only to prompt even more dissent and discredit. This is the object of the next section.

\section{The Reaction of French Political Economy}

In order to understand French economists' response to positivism, it is essential to put it back into perspective. When positivism climaxed on the French intellectual scene in the 1840s-50s, political economy had already been targeted by a number of detractors either grouped under the then popular Romantic Movement or under the dazzling Saint-Simonianism. Social thinkers, who then included socialists but also Romantics and Saint-Simonians, first attacked what they considered as a cold and spiteful attitude towards the poor. The blame will later be relayed by positivist thinkers and in particular by Auguste Comte. Despite embodying different philosophical and epistemological approaches, Romanticism $^{4}$ and Saint-Simonianism all concurred in their condemnation of classical political economy. Despite their obvious differences, Romantics and Saint-Simonians shared a profound dislike for the classical model of political

\footnotetext{
Romanticism developed in France at the very beginning of the nineteenth century under the joint influence of Madame de Staël and of Benjamin Constant. De l'Allemagne, published in 1813, is often considered as of one of its seminal productions. Romanticism is first of all a literary and artistic movement and has consequently no particular dealings with economics. Strongly influenced by Fichte, Schelling and Schlegel on one side and by Rousseau on the other side, Romanticism developed its own philosophy. Despite its strong eclecticism, it can be described as an overall rejection of the intellectual legacy of the French Enlightenment, namely materialism and utilitarianism.
}

economy which they considered unduly indifferent to social and historical realities. Lambasted for their (lack of) social policy and their outmoded scientific approach, French economists became widely unpopular. Methodologically speaking, Jean-Baptiste Say was following the guidelines of the philosophical movement of the Idéologues to which he belonged (Magnan de Bornier and Tosi 2003). He favored reasoning as a way to uncover truth but did not entirely ignore the role of observation ${ }^{5}$. Jean-Baptiste Say's followers, however, developed a more rigid epistemological view. For the immediate successor of Say at the Collège de France, Pellegrino Rossi, political economy was a science of reasoning rather than of observation. Those who maintained the contrary, he argued, were confusing "the rational or pure political economy' with 'the applied political economy". The distinction between pure (or "rational") and applied economics, also adopted by other economists, reflected a radicalization of Say's ideology: facts (and their historical observation) were now excluded from "the exact science" of "pure political economy' and relegated to the more philosophical (and hence less scientifically rigorous) "applied political economy".

Romantics, first, had grown wary, when not openly critical, of French and English economists ${ }^{6}$. A common source of dissatisfaction lied in the deductive method used by economists

When they are consistent with general laws, i.e. when they are 'general facts', historical facts can be useful but history must be employed with great care. In direct line with the philosophers of the Enlightenment he drew his inspiration from Destutt de Tracy. He believed that isolated facts or distorted accounts of the past were especially harmful to any scientific approach. History is acceptable, and indeed useful to rational analysis, when it is not 'romanticized'. Destutt de Tracy, like Say, was not yet favorable to the use of mathematics in political economy. Up to the 1840 s, and the publication of Cournot's Recherches sur les principes mathématiques des richesses (1838), this position remained almost unchallenged. It remained so for a few decades still, leaving Dupuit rather isolated in the Société d'économie politique (Breton 1986).

English economists have also been attacked by the Romantics who ridiculed their stereotyped description of human behavior. Malthusian economists were also harshly criticized for their social and moral inflexibility. Their opposition to poor relief, in particular, in the dreadful circumstances England was then experiencing after almost a decade of war and the Continental Blockade, shocked the public across the political board. Whether they are Malthusians (i.e. supporting Torries' interests) or Ricardians (i.e. supporting Whigs' interests), economists are singled out for their utter lack of humanity. Political economy greatly suffered in England from its reputation of being a 'dismal science' according to Thomas Carlyle's expression. See S. Collini, D. Winch, and J. Burrow, That Noble Science of Politics: A Study in Nineteenth-Century Intellectual History, Cambridge University Press, 1984. 
(such as Say and Ricardo) who proposed to uncover a universal pattern in economic behavior. This pattern, based on self-interest, was - according to the Romantic thinkers - neither universally nor historically verified. They furthermore believed that individuals are endowed with a much stronger moral and social nature than they are being given credit for. Romantics, such as George Sand or Félicité de Lamennais, would rather see political economy as a means to adapt institutions and to improve working conditions than as the sterile academic verbiage they think it has become after Adam Smith. Supporters of the contemplation of nature, Social Romantics were yet strongly inclined to political and economic reforms. This they shared with socialists such as Pierre Leroux, with whom they were close, and with the Saint-Simonians whom they influenced. Romanticism dramatically ended in France with the bitter failure of Victor Hugo's play, Les Burgraves, in 1843.

Unlike Romanticism, the movement initiated by Saint-Simon fundamentally belonged to a Cartesian tradition. Ultimately for Saint-Simon, like for Sismondi, the purpose of political economy should not be the sanctification of economic markets but the discovery of the mechanisms behind their failures and, when possible, the setting up of remedies to their crisis. In order to do this, political economy needed to quit its metaphysical foundations. Rossi, Chevalier, Garnier, Courcelle-Seneuil all defended the economic doctrine of free trade previously held by Jean-Baptiste Say. So far, most economists (with the notable exception of Sismondi) had defended the virtues of the free market. In the 1830s-1840s, however, economic liberalism grew more assertive, or even more aggressive. Amongst the fiercest partisans of a State-free economy was Frédéric Bastiat, Justice of the Peace in South-West France, who gained intellectual renown after publishing his first article in the Journal des Économistes in 1844 (Leroux 2011). Despite his premature death in 1850 (aged 49), Bastiat played a leading part in the ideological radicalization of French political economy, in particular through his contributions to the above mentioned journal. His successor, Gustave de Molinari, fled to exile in the 1850 s to escape the regime of Napoléon III, but later played an important part in the radicalization of the liberal creed as a regular contributor to the Journal des Débats (1871-1876) and as the chief editor of the Journal des économistes (1881-1909).
Bastiat and Molinari were not yet isolated in their beliefs. Even the most tolerant economists were then fervent supporters of free market. Charles Dunoyer, for instance, a close friend of Auguste Comte and known for his social concern, nevertheless thought that medical diplomas should not be necessary to register as a doctor considering that the market would soon cast aside quacks (Breton 1985, 240).

For Saint-Simon, society should be organized relatively to its economic efficiency rather than to its political legitimacy with industrial manufacturing as model for political organization. Saint-Simon hence proposed to substitute democratically elected politicians by duly appointed industrialists and financiers, a proposition met by liberal economists such as Charles Comte and Charles Dunoyer with great skepticism (Halevy 1938, 39). In addition to being politically unsettling, his system was also questioning the capacity of the market to self-regulate. Economists from Quesnay to Say or Ricardo had been mistaken to believe that their science was relying on timeless and universal laws. Political economy, said Saint-Simon, belonged to social sciences and, as such, could not be studied independently from the society itself. And society could not be apprehended out of the history of its evolution. Saint-Simonianism partly fell apart during the $1830 \mathrm{~s}$, victim of internal dissensions (in particular between Enfantin, Chevalier and Bazard) and the growing appeal of socialism. Its philosophy of history, however, continued to develop through positivism.

To a large extent, Romanticism and Saint-Simonianism failed in their attempt to sway political economy towards empiricism and historicism. The intellectual aura and political influence of Jean-Baptiste Say probably protected the French economists against the joint attack of Romanticism and Saint-Simonianism. After his death in November 1832, however, French political economy found itself in a precarious situation characterized by the lack of a new intellectual leader and the emergence of positivism. Unlike in England, Romanticism in France never really constituted a serious threat for political economy, possibly because of its deep-rooted anti-Enlightenment. Saint-Simonianism, on the other hand, influenced some of the most important economists of the time, like Michel Chevalier, or, on a different level, Proudhon. When Saint-Simonianism faded away, positivism 
replaced it in its social and epistemological criticism. But Comte constituted a far more serious challenger than Saint-Simon ever was for political economy. Saint-Simon used political economy to build on his political system. Comte used his philosophical system to write off political economy. A much stronger response was needed. The decades that immediately followed Say's death saw French political economy organizing itself and contending with sociology for political expertise.

Despite newly created chairs of political economy ${ }^{7}$, economists were frustrated by the lack of recognition they got from the public and the government. According to Yves Breton, "economists who had a high notion of their knowledge and of their mission had a dual ambition throughout the period 1830-51. They wanted to inspire the political power and to extend the existence of a social order that, they believed, was jeopardized and attacked on all sides." (Breton 1985, 250). To this end, it was imperative for them to form a common front. Historical methods, such as the one promoted by positivism, were regarded with great suspicion by liberal economists because they could be instrumental in legitimizing protectionist policies ${ }^{8}$. A Société d'économie politique was then created in 15 th November 1842 (after a failed attempt by Rossi) alongside

The first chair of political economy in the Collège de France was established in 1831 and was offered to JeanBaptiste Say who was the unopposed leader of the French political economy. Too ill to teach, the lectures were handed over to his son Horace instead. In 1833, after Jean-Baptiste Say's death, the chair was then awarded to Pellegrino Rossi who held it till 1840. The same year, Adolphe Blanqui inherited the chair of industrial economics, established by Jean-Baptiste Say in 1819, at the Conservatoire des arts et métiers (Arena 1991). In 1832, Guizot created a department of political economy and statistics at the Académie des sciences morales et politiques to "guide the government on the progress made by those disciplines and on the decisions to be taken relatively to its teaching" (Van-Lemesle 2004, 81). A new chair of political economy was also established in 1846 at the École des ponts et chaussées. The young republican and liberal economist, Joseph Garnier, was entrusted with it.

8 Friedrich List, in Das nationale System der politischen Oekonomie (1841, translated into French in 1851), hence defended the idea that if free trade should be the rule in fully developed countries (those having reached the fourth and last historical stage), protectionism could be justified for those whose industries were not yet strong enough to face international competition. the Journal des économistes ${ }^{9}$ in order to give some visibility to economists and scientific credibility to their liberal doctrine. The society was established by Joseph Garnier, Gilbert Guillaumin, Eugène Daire, Adolphe Blaise and a fifth person ${ }^{10}$, who, "very soon found himself out of place and who ended up by arguing against political economy and defending the principle of custom tariff protection!" (Breton 2013, 53-54).

French economists were determined to avoid such beliefs developing in their midst. Huge efforts were thus being made to try to correct the "bad" impression given by diverging theories, which like those of Dunoyer, Wolowski or Baudrillart, who gave a prominent place to history. The Preface to the new Dictionnaire de l'économie politique that Guillaumin published with Charles Coquelin in 1853-1854, was — on that point - perfectly clear: "all our energy has been focused on presenting a unique doctrine despite the number of authors and the variety of their opinions so that our book could be used by the reader as a guide through the contradictory doctrines that have been produced, especially nowadays. It has therefore been intentionally titled Dictionnaire de l'Économie Politique preferably to Dictionnaire d'Économie Politique." (Coquelin and Guillaumin 1864, v). Joseph Garnier adopted a similar objective in his various "treatises", "elements" or "abstracts" of political economy: minimizing the differences of opinions between the economists to present a core knowledge (that he calls a 'grammar') of economics. He particularly stressed on the importance for political economy to conform to the scientific standards used in physics or biology.

Internal dissents climaxed at the beginning of the 1860s, when Jules Dupuit, an economist who originally trained as a civil engineer, directly accused his heterodox colleagues of be-

\footnotetext{
The Journal des économistes published its first issue in December 1841. This was not the first publication specialized in economics but it was the most successful (Laurent and Marco 1996, 81-82). A number of other periodicals were launched after 1830, such as the Revue nationale (created by Adolphe Blanqui), the Revue mensuelle d'économie politique, or the Journal de l'industriel et du capitaliste but they did not receive the same level of attention as the Journal des économistes.

10 In his Notice Historique, published in 1889 in the first issue of the Annales de la Société d'économie politique, Alphonse Courtois, then Permanent Secretary of the aforesaid society, negates to mention the name of the man "whose talent could not preserve him from oblivion"(Paris 1889, 5). Dissenting opinions were obliviously not welcome in this debating society.
} 
ing responsible for the lack of scientific credibility political economy was then suffering from. The attack was made during a debate that he himself launched at the Société d'économie politique in April 1864. The topic of the debate, "Why has political economy failed in being acknowledged by the public as a science?", explained Dupuit, had been triggered by a public speech by the Senator André Dupin, who had declared that political economy was a study rather than a science. André Dupin was the brother of Charles Dupin, a chartered engineer and mathematician, member of the Parliament, who - like his brother at the Senate- opposed the free-trade doctrines of the economists (Breton 2005). This was not the first time Dupuit brought up the question. He first reacted to Dupin's comment in an article published in the Journal d'économie politique, published in February 1863 (Dupin's words were pronounced on 29th March 1862), and entitled "L'économie politique est-elle une science ou n'est-elle qu'une étude?" (Dupuit, Breton, and Klotz 2009, 135-149). Between February 1863 and April 1864 no less than six articles were published in the JDE on this subject. Dupuit's virulence prompted Baudrillart to intervene and to withdraw one of his communications (Dupuit, Breton, and Klotz 2009, 163-71). For Dupuit, there was no doubt that economists themselves were responsible for their own predicament. If political economy was not yet acknowledged as a proper science, like astronomy, mechanics or physics, this was only because some economists were as bold as to challenge the main laws of economics and to contest Ricardo, Malthus or Say's demonstrations. In France, this intellectual rebellion, Dupuit reckoned, dated back to Rossi's death in 1848 (Dupuit, Breton and Klotz 2009, 157-58). Baudrillart, Levasseur and Batbie confronted him. They objected to Dupuit that discussing or even disputing doctrines did not make them less scientific, and that debating was unavoidable in "moral and political sciences". Batbie sarcastically added that a science that would need an institution (such as the JDE) to reduce the recalcitrant to silence would not really be a proper science. There was no official winner in the debate, but the guardians of the orthodoxy were soon to be overtaken by history. The classical economists' attempt to reassert their scientific authority by modeling hard science could indeed not have been more untimely. The 1863 elections had just lead to power a new group of men more favorably disposed towards positivism.

\section{Political Economy Redeemed}

It is often assumed that Napoléon III was openly adverse to political economy and its free-trade principles. This is partly true. The first years of the Second Empire have certainly been tough for the French economists. Gustave de Molinari and Jean-Gustave Courcelle-Seneuil, who took a position in favor of the Second Republic, were forced into exile after December 1851: Molinari flew to Belgium whilst Courcelle-Seneuil sailed off to Chili. Jean-Baptiste Say's chair of the Conservatoire national des arts et métiers, held by Adolphe Blanqui since in 1833, was suppressed at his death in 1854. If Joseph Garnier, Louis Wolowski and Henri Baudrillart were still allowed to practice, their classes were closely watched (Van-Lemesle 2004, 123). The fate of French political economy, however, completely changed during the 1860s: Michel Chevalier was summoned to negotiate a free-trade treaty with England, Courcelle-Seneuil and Molinari were allowed to return from exile and new chairs of political economy were created.

This radical change is usually accounted for by a political reorientation of the Empire ${ }^{11}$ and by the consecutive rallying of the liberals to the Empire (Van-Lemesle 2004). The victory of the Republican opposition in the 1863 elections (provoked by the new constitution endorsed in 1862) radically changed the political scene. But this does not entirely explain the economists' return to favor. For one thing, liberal economists were not all republicans. Michel Chevalier, to name but one, opposed the 1848 Revolution (he temporarily lost his chair at the Collège de France as a result). Republicans, secondly, were not necessarily supporters of a free market economy. Their leader, Adolphe Thiers, was for instance a committed protectionist. Economists did not therefore rally to power in the 1860 s, nor did the emperor radically change his economic principles. They simply met on common grounds, namely, Saint-Simonianism and positivism. If Saint-Simonianism contributed to easing the relations

\footnotetext{
The first and most common historical explanation consists in dividing the Second Empire into two distinct phases: the "authoritarian Empire" (1852-1860) and the "liberal Empire" (1860-1870). See, for instance, (Antonetti 1997)
} 
between the power and the economists, positivism contributed to giving political economy a proper institutional and scientific status. They both considerably helped political economy to develop, but also to change and to adapt itself to the new intellectual standards. Two men played a decisive role, notably through their personal connection with the emperor, the economist Michel Chevalier and the historian and Ministre de l'Instruction, Victor Duruy.

Lampooned by Victor Hugo, Louis-Napoléon Bonaparte has often been described as intellectually mediocre and easily suggestible. This has, however, been recently contested (Sagnes 2008). Louis-Napoléon was well-read and intellectually proficient. He even published a certain number of books on military matters, on politics, on history (including biographies of Caesar and Napoléon) and on social issues ${ }^{12}$. This latter interest of his was prompted by the strong sympathy he developed towards saint-Simonianism in his youth and to which he remained faithful throughout his life. This accounts for his good relationship with Michel Chevalier, and more generally with saint-Simonian economists. After seeing his chair at the Collège de France suppressed, Michel Chevalier is immediately reintegrated into his position by the newly elected President Louis-Napoléon (Van-Lemesle 2004, 116-17). After his coup, the emperor took advice from him, and even asked him to see through the completion of a free-trade agreement with England. The agreement was successfully completed (with Richard Cobden representing England) in 1860. Being in favor of free-trade does not necessarily imply being adverse to all kinds of public intervention. Michel Chevalier noticeably supported a State intervention in the labor and education market (Breton 1991b). His step-son, Paul Leroy-Beaulieu, who was also a fervent partisan of economic liberalism, promoted public policies (and subsidies) to increase the French population (Baslé 1991). It was no less consistent for Louis-Napoléon to both support social regulations and to sign free-trade agreements.

Almost completely forgotten today, Victor Duruy has probably been one of the most influential reformers of the French modern education system. Yet, he was neither a politician nor

12 He published, in particular, Extinction du paupérisme in 1844 and Discours de M. le Président de la République sur les améliorations à apporter au bien-être des classes ouvrières in 1849. an academic. Duruy was but a mere historian whom Napoleon III took under his protection and imposed - against all odds - at the ministry of education after the elections of 1863 . This was his only interference with the composition of the new government. With Duruy, the French higher education was entrusted to positivists. Duruy is a historian very much indebted to the positivist Hippolyte Taine, whom he appointed in 1864 at the École des Beaux-Arts. Emile Levasseur, who became responsible for the economic teaching in the Écoles spéciales, was an opponent of Walras and the École de Lausanne.

Duruy's principal achievement (for what concerns us here) was to (re)introduce political economy in French universities. He did not completely succeed in doing so since political economy was only introduced in the law faculties in 1877 . But, as shown by the following letter between Duruy and the emperor, the fault does not lie with him but with the inertia of the French University: "I beg the Emperor to consent to take a look at a letter sent to me by a Polish Count. He is bringing to my attention an intentional shortcoming in the decree, one relating to the economic or cameral sciences as they say in Germany. I say intentional because I did not find any positive feedback at the faculty of Law when I tried to persuade them and that I have at this very moment the German system reviewed relatively to this kind of study. It's not cancelled but only postponed. A note at the bottom of the decree signals this intention, which is, I believe, in the Emperor's mind." (Duruy 1901, 317-318).

Alternative solutions were found meanwhile by Duruy. Political economy was first introduced in the program of the newly created Écoles spéciales under the supervision of Emile Levasseur. Adople Blanqui's chair at the Conservatoire des arts et métiers, suppressed in 1854, was reestablished and jointly attributed to Jules Burat and Louis Wolowski. A special chair in political economy was also created at last in the law faculty in Paris and was assigned to Anselme Batbie (Van-Lemesle 2004, 171-74). These were only isolated trials but they prepared the way for the introduction of political economy in all French law faculties by 1877 . Political economy was finally almost predominant in the privately funded Ecole $\mathrm{Li}$ bre des Sciences Politiques (now Institut des Sciences Politiques) established in 1871. Out of six courses offered at its opening, remarks 
Lucette Le Van-Lemesle, three were devoted to a history-oriented political economy: 'History of the Economic Doctrines since Adam Smith' given by Anatole Dunoyer (Charles Dunoyer's son), "History of the Agricultural, Commercial and Industrial Progress" given by Emile Levasseur and "Financial History of Europe since the French Revolution" given by Paul Leroy-Beaulieu (Van-Lemesle 2004, 209).

As it can be seen, the recipients of the recently created jobs were all in favor of the historical method in economics. Those who were partisans of a deductive science of economics, such as Courcelle-Seneuil, Cournot or Walras, did not benefit from the newly established teaching positions ${ }^{13}$. The choice of the courses offered by the École libre des Sciences Politiques bore the influence of the positivist historian Hippolyte Taine, who largely contributed to its creation (Seys 1999). Law faculties, in which political economy was eventually introduced, were generally agreeable to the historical method (Breton 1991a, 402). The economists who embraced the historical method were therefore clearly advantaged over those who did not. They earned institutional positions and social recognition. This had, in particular, a major and lasting implication for the development of history of economic thought.

The emergence and the shaping of history of economic thought within the economic corpus were indeed largely determined by positivism. It is, firstly, highly probable that history of economic thought would not have emerged at this particular time, or at least would not have developed as much, if Duruy had not trusted chairs of political economy with sympathizers of the historic method. Secondly, it is clear that history of economic thought, as it was then practiced, was influenced by the positivist approach of SainteBeuve. It is important first to remember that history of economic thought has not always been valued by the economists. Rossi, in his Cours d'économie politique (1840), only mentioned Quesnay a few times, usually to praise his liberalism. He did not, however,

13 Courcelle-Seneuil did not hold a chair before 1881, Walras was given one in Lausanne in 1870 and Cournot never got a teaching position in economics. Dupuit died in 1866 quote Turgot. Most economic textbooks did not mention them at all ${ }^{14}$. The situation really began to change around $1860^{15}$. Publications in history of economic thought surged and climaxed before the First World War before steadily declining since. Positivism explains, at least for a part of it, the sudden fortune of history of economic thought. As a result of the chairs in political economy being held by positivist historians or historian economists, it naturally constituted a larger part of the economic syllabus. Baudrillart, for instance, published his Etudes de philosophie morale et d'économie politique in 1858 in which he devoted complete chapters to past economists, including Turgot, Quesnay and Destutt de Tracy, whom he also discussed in his Manuel d'économie politique published in 1857. Likewise, his Économie politique populaire (1869) included a chapter on Vauban. Doing the history of economic thought was simply for them a way of doing political economy. Actually most of their economic

14 Neither were they mentioned by Molinari in his Questions d'économie politique et de droit public (1861). Nor are they, for instance, in L.F.G. de Cazaux's Bases fondamentales de l'économie politique, d'après la nature des choses (1826), or in Ch. Le Hardy de Beaulieu's Traité élémentaire d'économie politique (1861), or in C. Ganilh's Théorie de l'économie politique fondée sur les faits résultans des statistiques (1815), or in M. Agazzini's Science de l'économie politique (1822), or in J. Pautet's Manuel d'économie politique (1835), or in F. Larreguy's Economie politique (1834), or again in C. de Brouckebe's Principes généraux d'économie politique (1851). Rare mentions of Quesnay and/or Turgot are found, in particular, in J. Droz's Economie politique ou Principes de la science des richesses (1829), in G. Courcelle-Seneuil's Traité sommaire d'économie politique (1865), in A. Blanqui's Précis élémentaire d'économie politique (1857), in N. Urbain's Introduction à l'étude de l'économie politique (1823), in C. de Coux's Essais d'économie politique (1832), or in J. Dutens' Philosophie de l'économie ou nouvelle exposition des principes de cette science (1835).

15 One of the earliest historians of economic thought was probably Théodore Fix, author of the Observations sur l'état de la classe ouvrière (1846), and who published in 1830 a surprising Economie politique: coup d'œil sur la science de l'économie politique. Just after, J.P. Alban de Villeneuve and Blanqui both published a Histoire de l'économie politique (respectively in 1839 and 1837-42), although the latter dealt very little with economic thought. But this did not really compare with the string of books specializing in history of economic thought and published during the last decade of the Second Empire. Let us mention, for instance, J.E. Horn's L'économie politique avant les physiocrates (1867), awarded by the Académie des sciences morales et politiques (which had launched a competition on Boisguilbert), F. Cadet's Histoire de l'économie politique: Les précurseurs (1869) on Boisguilbert, Vauban, Quesnay and Turgot, and the curious G. du Puynode's Etude sur les principaux économistes : Turgot- Smith-Ricardo-MalthusSay-Rossi (1868), which excludes Quesnay from the great economists. 
textbooks used at some point some historical references to support a particular argument. Historical introductions to economic treatises or textbooks became also more common $^{16}$. Conversely it was not unusual at the time to discuss current economic issues in specialized publications in history of economic thought. Batbie - for instancedevoted a large part of his monograph on Turgot (1861) to develop his own arguments on current economic matters (Batbie 1861). Economic theory and history of economic thought were then closely interconnected.

Note that history of economic thought was not yet exclusive to heterodox economists. It was embraced by some of the founding members of the Société d'économie politique, like Joseph Garnier and Gilbert Guillaumin. But their reasons for turning towards past economic writers significantly differed from those one would expect from positivist thinkers. They usually saw in them a way to support their free-trade doctrine and to restore the much deteriorated image of political economy. Turgot and Vauban, in particular, were unanimously considered with respect in France at the time and benefited, in particular, from an excellent moral reputation. In his Histoire de l'économie politique (1869), Félix Cadet particularly emphasized this point. For him, the courage, the disinterest, and the truthful love of justice showed by all the 'illustrious' past thinkers studied (Boisguilbert, Vauban, Quesnay, Turgot, Smith, Franklin, Say, Cobden, Bastiat) was the best reply one could make to the opponents of political economy (Cadet 1869, 1). Past authors were therefore chosen and interpreted so that they could always appear supportive of the free-trade principles of their successors. Two major editorial undertakings belong to this category, Guillaumin and Coquelin's Dictionnaire de l'économie politique (1854), which devoted full articles to the economists aforementioned and, of course, Guillaumin and Daire's edition of the 'principaux économistes'

16 See, for instance, Emile de Girardin's introduction to A. Chargueraud's L'économie politique et l'impôt (1864), or the historical introduction Louis Louvet gives to his Curiosités de l'économie politique (1861). published between 1841 and 1852 . Gilbert Guillaumin ${ }^{17}$, one of the founders of the Journal d'économie politique, undertook the publication (with Eugène Daire) of a 15 volume series called Collection des principaux économistes, composed essentially of the writings of Quesnay, Turgot, Smith, Ricardo, Malthus and Say. Apart from Jean-Baptiste Say's works, which were relatively easy to obtain, this series - published between 1840 and 1847- constitutes the first accessible publication of the major economists in French. Numerous comments have been included by the editors to facilitate the reading of the thenceforth "classics" but also to correct what they considered as "youthful mistakes" of a newly born science. For them, history of economic thought was a way to morally rather than to scientifically justify political economy. Yet, even then, they did not entirely escape the influence of positivism.

The novelty of the history of economic thought within political economy, partly prompted by Duruy's reforms, partly used by liberals to build themselves a good reputation, left the economists largely unprepared. If economic methodology had been largely debated over the last decades, the proper methods of the history of economic doctrines or ideas had never been really discussed. Seriously lacking in experience, the first historians of economic thought naturally turned towards literary criticism. The development of history of economic thought between, say, 1850 and 1870 indeed almost exactly matched the construction of a positivist literary criticism, best embodied by Charles-Augustin Sainte-Beuve ${ }^{18}$. SainteBeuve, who originally wanted to become a physician, was, alongside Taine and Comte, one of the most famous positivists of the nineteenth-century. His own scientific model was natural history; he even compared himself to Buffon looking "to create a natural history of

7 In their obituary, Henri Baudrillart and Hippolyte Passy both paid tribute to the role played by Guillaumin in the development of French political economy at a time when, they say, it received nothing but indifference from public opinion. Journal des économistes, 15 janvier 1865, t. XLV, pp. 109-111.

18 In 1848, Sainte-Beuve was given a chair in Liège and teaches on Chateaubriand. From 1849 on, he published each week what will become his 'Monday Chats' in various newspapers. He died in 1869. 
literature" (Lepenies 2013, 385). His aim was to explain rather than to judge literary works. His method was biographical, always relating the literary production to the life and character of its author. His method had been vilipended by Marcel Proust and has since fallen into disregard. At the time, however, it was considered cutting-edge. By focusing on the author's biographies rather than on their expressions, ideas, or concepts, it claimed to discover the true intended meaning of the text. This largely explains why the first historians of economic thought gave so much importance to the past economists' life and character ${ }^{19}$. This naturally impacted on the choice of the economists studied. Biographies of economists, who also happened to be great figures of French history, such as Boisguilbert, Turgot or Vauban, were preferably chosen over 'pure' economists, and French economists were systematically preferred to English ones. The absence of biographical details may also explain the relatively small place given to Quesnay in comparison to Turgot or Vauban for instance. His famous Tableau économique, for which he is acknowledged today as one of the greatest economist in history, was then barely even mentioned. This only began to change with Marx and Walras who first saw its theoretical strength. For a large part of the twentieth-century, history of economic thought looked for theoretical breakthrough and conceptual innovations in order to justify the study of past authors. At the time, however, history did not need justification. On the contrary, it was used by economist as a moral and scientific justification of their own work. Times changed.

\section{Conclusion}

The decades following Jean-Baptiste Say's death were, I argued, characterized by an epistemological and ideological radicalization of
French economics, which largely explains its unpopularity and lack of credibility with the intellectuals then largely won over by positivism. In order to restore their scientific authority and to speak with one voice, French economists gathered in an intellectual society and launched a journal in 1842 . But still they faced strong internal dissent relative to the use of the historical method in political economy. The debate climaxed in 1864 when Jules Dupuit accused the 'heterodox' economists of adversely affecting the political and scientific authority of economics. The elections of 1863 and the subsequent appointment of Victor Duruy as the Secretary of State for Education turned the tables to the advantage of the heterodoxies. Institutional changes, brought forward by the new government in 1864 officially promoted political economy in general, but the changes really benefitted positivist economic thought, to the detriment of the classical economists. Those institutional changes had significant epistemological implications for French political economy. The principal one, I believe, was to stimulate historical approaches to political economy and in particular research on past economists. Positivism was admittedly not entirely responsible for the development of history of economic thought in France, but it certainly contributed to it by institutionalizing a political economy more opened to the historical method and by steering it towards a biographical method. History of economic thought mainly thrived in the second half of the nineteenth-century because it then perfectly addressed the needs of a political economy plunged into a moral and scientific crisis. Not only did history of economic thought fully comply with the scientific norms imposed by positivism, but it also offered, to the liberal's great delight, a convenient response to the moral attacks launched, in particular, by the Romantics and the Catholics. 


\section{References}

Alengry, Franck. 1899. Essai historique et critique sur la sociologie chez Auguste Comte. Thèse présentée à la Faculté des lettres de l'Université de Paris, par Franck Alengry, Paris: F. Alcan.

Antonetti, Guy. 1997. Histoire contemporaine politique et sociale, Paris: Presses universitaires de France.

Arena, Richard. 1991. Adolphe-Jérôme Blanqui 1798-1854. Un historien de l'économie aux préoccupations sociale. In L'Economie politique en France au XIXe siècle, edited by Yves Breton and Michel Lutfalla, Paris: Economica, pp.163-83.

Baslé, Maurice. 1991. Paul Leroy-Beaulieu 1843-1916. Un économiste français de la IIIe République commençante. In L'Economie politique en France au XIXe siècle, edited by Yves Breton and Michel Lutfalla, Paris: Economica, pp.203-46.

Batbie, Anselme. 1861. Turgot : Philosophe, économiste et administrateur. Paris: Cotillon éditeur.

Bourdeau, Michel. 2012. Auguste Comte Et La Religion Positiviste. Paris: J. Vrin.

Breton, Y. 2013. The Société d'Economie Politique of Paris (1842-1914). In The Spread of Political Economy and the Professionalisation of Economists: Economic Societies in Europe, America and Japan in the Nineteenth Century, edited by Marco Guidi Massimo Augell. London: Routledge,pp. 53-69.

Breton, Yves. 1985. Les économistes, le pouvoir politique et l'ordre social en France en 1830 et 1851. Histoire, économie et société 4 (2). 233-252.

Breton, Yves. 1986. Les économistes libéraux français et l'emploi des mathématiques en économie politique 1800-1914. Économies et sociétés, Mars, vol.5. 25-63.

Breton, Yves. 1991a. Les économistes français et les questions de méthode. In L'économie politique au XIXe siècle, edited by Yves Breton and Michel Lutfalla. Paris: Economica.

Breton, Yves. 1991b. Michel Chevalier 1806-1879. Entre le saint-simonisme et le libéralisme. In L'Economie politique en France au XIXe siècle, edited by Yves Breton and Michel Lutfalla, Paris: Economica, pp.247-75.

Breton, Yves. 2005. French Economists in Parliament from the Second Republic to the Outbreak of the Great Crisis (1848-1929). In Economists in Parliament in the Liberal Age (1848-1920), pp.129-162.

Cadet, Félix. 1869. Histoire de l'économie politique: Les précurseurs Boisguilbert, Vauban, Quesnay, Turgot. Reims: H. Gérard.

Coquelin, Charles, and Gilbert-Urbaain Guillaumin. 1864. Dictionnaire de l'économie politique. Paris: Guillaumin et cie.

Dupuit, Jules. 2009. CEuvres économiques complètes, Edited by Yves Breton and Gérard Klotz. Paris: Economica.

Duruy, Victor. 1901. Notes et souvenirs (1811-1894). Vol. 1. Paris: Librairie Hachette.

Evans, David Owen. 1951. Social Romanticism in France, 1830-1848: With a Selective Critical Bibliography, Oxford: Clarendon Press.

Halevy, Elie. 1938. L'Ere des tyrannies. Paris: Gallimard.

Laurent, Eric and Luc Marco. 1996. Le 'Journal des économistes', ou l'apologie du libéralisme (18411940). In Les revues d'économie en France: genèse et actualité, 1751-1994, edited by Luc Marco, Paris: L'Harmattan, pp. 79-120.

Lepenies, Wolf. 2013. "Charles-Augustin Sainte-Beuve (1804-1869) " In The Cambridge History of Literary Criticism, edited by M.A.R. Habib, Cambridge: Cambridge University Press, pp.379-92.

Leroux, Robert. 2011. Political Economy and Liberalism in France: The Contributions of Frédéric Bastiat, London: Taylor \& Francis.

Le Van-Lemesle, Lucette. 2004. Le Juste ou le Riche: l'enseignement de l'économie politique 1815-1950, Paris: Comité pour l'histoire économique et financière de la France.

Levy-Bruhl, Lucien. 2007. Correspondance de John Stuart Mill et d'Auguste Comte, Paris: Harmattan.

Magnan de Bornier, Jean, and Gilbert Tosi. 2003. "La méthode de Jean-Baptiste Say: au service d'une discipline autonome'." Jean-Baptiste Say: nouveaux regards sur son oeuvre, Paris: Economica, pp.4468.

Mauduit, Roger. 1929. Auguste Comte et la science économique, Paris: F. Alcan.

Petit, Annie. 1992. «Comte et Littré : les débats autour de la sociologie positiviste». Communications. 54 (1). $15-37$

Picard, Roger. 1944. Le Romantisme social, New York: Brentano’s. 
Pickering, Mary. 1993. Auguste Comte: An Intellectual Biography, Volume 1, Cambridge: Cambridge University Press.

Pickering, Mary. 2009. Auguste Comte: An Intellectual Biography, Volume 3, Cambridge: Cambridge University Press.

Poisson, Jacques. 1931. Le romantisme social de Lamennais: essai sur la métaphysique des deux sociétés: 1833-1854. Paris: J. Vrin.

Sagnes, Jean. 2008. Napoléon III: le parcours d'un saint-simonien, Paris: Editions Singulières.

Seys, Pascale. 1999. Hippolyte Taine et l'avènement du naturalisme: un intellectuel sous le Second Empire, Paris: L'Harmattan.

Simon, W.M. 1963. European positivism in the nineteenth century: an essay in intellectual history, Ithaca, Cornell University Press. 